\title{
Unveiling the Senior Sexuality: an Integrative Review \\ [REVII
}

\begin{abstract}
Kamilla Abrantes de Sousa ${ }^{1}$, Renata Lívia Silva Fonsêca Moreira ${ }^{2}$, Karolliny Abrantes de Sousa ${ }^{1}$, Rayrla Cristina de Abreu Temoteo ${ }^{1}$, Marcelo Costa Fernandes ${ }^{1}$, Iara Diogenes Silva ${ }^{1}$
\end{abstract}

\section{Abstract}

This study aimed to analyze the national and the international literature, the perception and experience of sexuality by the elderly person. It was accomplished through Integrative Review, with searches made in the databases BDENF, LILACS, SCIELO and MEDLINE using the DECS "elderly", "health of the elderly" and "sexuality", by selecting 10 articles after inclusion and exclusion criteria. The analysis emerged three categories, covering respectively: the complex definition of sexuality by the elderly, significant changes to existing after the aging that interfere with sexuality and the importance of health education in addressing this issue to guide seniors and elderly not to experience it naturally. It is concluded that the knowledge and approach of sexuality in old age are important and should happen in the consultations with the old man leaving him free to share his questions and experiences.

\section{Introduction}

Population aging is the change in the age structure of the population, which increases the relative number of people above the age that defines the onset of old age. Brazilian elderly are about 60 years old or over. In recent years, the elderly population has grown quickly and because of this, the age pyramid of triangular shape is giving way to a pyramid with narrower and wider vertex basis. Thus, Brazil will occupy the sixth place as the number of seniors who will be, in 2025, about 32 million [1].

Currently, in Brazil there are approximately 20 million people aged over 60 years old, representing at least 10\% of the population [2] and with projections for a growing increase, it is important to the creation and improvement of public health policies for the elderly person; dealing with the health status of the elderly in all its comprehensiveness covering biopsychosociocultural features.
1 Federal University of Campina Grande, Cajazeiras, PB, Brazil.

2 Faculty Santa Maria, Cajazeiras, PB, Brazil.

Contact information:

Renata Lívia Silva Fonsêca Moreira.

झ renaliviamoreira@hotmail.com

Keywords

Elderly; Health of the elderly; Sexuality. 
One can define sexuality as the way in which each individual is expressed through actions like the look, the smell, the exchange of sounds, touch and caress, not simply summarizing the sexual act and suffering influence of hormonal factors, emotional and socio-cultural. It is very important for self-esteem of the human being to maintain a healthy and satisfying sex life and this exercise is a natural practice that should happen throughout life, even in old age. At this stage, sexuality becomes more related to the life story of each senior and his affective, cultural and historical values. [3]

It is common to see the difficulty of addressing the issue of sexuality of the elderly, because there is still a lot of myths and taboos and lack of information about the physiological needs and desires that continue to exist after aging. The growing elderly presence in today's society requires a new approach, especially in the approach to sexuality, to be a topic difficult to understand and limited vision, which makes classify old age as a time of asexuality and sacrifices, in which they cannot keep their sexuality [4].

So, the present study will approach how the elderly perceive their sexuality and experiences in this stage of life, in order to understand that it is possible to keep a healthy sexuality with consequent improvement in quality of life after aging. This research will be important for the information about elderly sexuality being disclosed and allow professionals and society to understand and deal with fewer taboos, as part of the life cycle of every human being and it is not necessary to leave to practice it in old age.

Therefore, the aim of this study was to analyze the national and international literature, the perception and experience of sexuality for the elderly.

\section{Method}

This is a study of an integrative review, specific method that synthesizes the results obtained in pre- vious studies above, showing the conclusions of the corpus of literature about the given phenomenon. The studies are related to the main question, which directs the search and choice of literature and summary data and compared allow general conclusions about the issue [5]. For its development there were followed the six steps outlined below [6]:

\section{First step: defining the guiding question}

After understanding the relevance of the research about this subject it was formulated the following question: "How is the perception and experience of sexuality for the elderly?"

\section{Second step: definition of inclusion and exclusion criteria}

There were used as inclusion criteria only articles that make available the full text, articles with free online version, national and international productions, which were published in Portuguese and English and published between the years 2010 to 2014. There were excluded theses, dissertations and monographs, articles differed with the theme after reading the abstracts, articles that do not have its resume available and publications repeated in the databases.

\section{Third step: choice of databases and search of scien- tific production}

The databases used for research were the Latin American and Caribbean Health Sciences (LILACS), Scientific Electronic Library Online (SciELO), Nursing Database (BDENF), Medical Literature Analysis and Retrieval System Online (MEDLINE ) using the association of Descriptors in health Sciences (DECS), "old", "health of the elderly" and "sexuality".

The search was carried out by the interweaving of DECS, when using "old" were found 2,725,975 articles, crossing it with "health of the elderly" were 156,855 articles, and adding "sexuality" were 307 articles that after placed the remaining filters 38 
items for evaluation of their titles and abstracts. After initial reading them and applying the inclusion and exclusion criteria, there were selected 10 articles for further analysis.

\section{Fourth step: data analysis}

The analysis of articles was through the construction of a summary table, which covered the following aspects: title search and journal, author, year, type of research and objective and main results.

\section{Fifth step: discussion of the data}

After free and exhaustive reading of these articles, it sought to similar results by dividing them into the following three categories: definition of sexuality and social roles; aging and sexuality confounders and sexuality and health education.

\section{Sixth step: review of synthesis}

The entire synthesis was based on evidence found in all the topics and items discussed in this review.

\section{Results}

According to the characterization of the publications, there were included 10 articles found in databases LILACS (05), MEDLINE (01), BDENF (02) and SCIELO (02). Of these, nine were in Portuguese and only one in the English language, as explained in Table 1.

It is shown in Table 1 that the research took place between 2010 and 2014, which proves to be more interesting for the scientific community. Among the three studies, there were qualitative research, two research-action, a case study, two cross-sectional studies and two integrative reviews, then the ma-

Table 1. Distribution of the publications included in integrative review according to the title of the research and the journal, the author and the year, search type and the purpose and the main results. LILACS, MEDLINE, BDENF, SCIELO 2015.

\begin{tabular}{|c|c|c|c|c|c|}
\hline $\begin{array}{l}\text { Title the } \\
\text { research }\end{array}$ & journal & Author & Year & $\begin{array}{l}\text { Research Type } \\
\text { and Objective }\end{array}$ & Main Results \\
\hline $\begin{array}{l}\text { The } \\
\text { representation } \\
\text { of sexuality } \\
\text { for elderly } \\
\text { and health } \\
\text { education. }\end{array}$ & $\begin{array}{l}\text { Electronic } \\
\text { Journal of } \\
\text { Nursing }\end{array}$ & $\begin{array}{l}\text { Baldissera, } \\
\text { V.D.A.; } \\
\text { Bueno, S.M.V. }\end{array}$ & 2010 & $\begin{array}{l}\text { Research-action, which aimed } \\
\text { to develop and evaluate health } \\
\text { education strategies based } \\
\text { on critical-social pedagogy at } \\
\text { the women with HAS a group } \\
\text { of participants meeting of a } \\
\text { health center in the Northwest } \\
\text { of Paraná-Brazil. }\end{array}$ & $\begin{array}{l}\text { There is difficulty to understand } \\
\text { and explain the sexuality by } \\
\text { these women, representing as } \\
\text { reductionism to sex and subtly. } \\
\text { Health education has allowed the } \\
\text { Exchange and led to the reflection } \\
\text { of sexuality collaborating with the } \\
\text { construction of common sense in a } \\
\text { less exclusive aspect. }\end{array}$ \\
\hline $\begin{array}{l}\text { Perception of } \\
\text { elderly women } \\
\text { about sexuality: } \\
\text { gender } \\
\text { implications } \\
\text { and nursing } \\
\text { care. }\end{array}$ & Rene Journal & $\begin{array}{l}\text { Coelho, } \\
\text { D.N.P.; Daher, } \\
\text { D.V.; Santana, } \\
\text { R.F; Santo, } \\
\text { F.H.E. }\end{array}$ & 2010 & $\begin{array}{l}\text { Qualitative research, aiming } \\
\text { to describe the perception of } \\
\text { elderly women about their } \\
\text { sexuality and to analyse the } \\
\text { gender implications in aging } \\
\text { female and nursing care. }\end{array}$ & $\begin{array}{l}\text { Reflected the influence of historical } \\
\text { cohort, characterized by a repressor } \\
\text { and education with rigid moral } \\
\text { values crucial in building the social } \\
\text { identity of the Brazilian woman, a } \\
\text { fact of controversial ideas about } \\
\text { sexuality. }\end{array}$ \\
\hline $\begin{array}{l}\text { Sexuality in } \\
\text { old age in the } \\
\text { perception of } \\
\text { an older group } \\
\text { and indications } \\
\text { for sexual } \\
\text { education. }\end{array}$ & $\begin{array}{l}\text { Health } \\
\text { Sciences } \\
\text { UNIPAR }\end{array}$ & $\begin{array}{l}\text { Frugoli, A.; } \\
\text { Magalhães } \\
\text { Júnior, C.A.O. }\end{array}$ & 2011 & $\begin{array}{l}\text { Qualitative research. Objective } \\
\text { to identify and describe the } \\
\text { knowledge about sexuality } \\
\text { among the elderly of the } \\
\text { group "walk good", as well as } \\
\text { analyze the level of knowledge } \\
\text { of STD/AIDS. }\end{array}$ & $\begin{array}{l}\text { It was observed that older considers } \\
\text { sexuality and sexual act being } \\
\text { synonyms; almost all claimed to } \\
\text { be possible to have an active and } \\
\text { healthy sex life in old age; no use } \\
\text { condom after the } 50 \text { years and have } \\
\text { doubts about the subject in need of } \\
\text { information. }\end{array}$ \\
\hline
\end{tabular}




\section{Title the research}

Fellowship and sexuality of couples in the best age: taking care of the elderly couple.

journal

Brazilian

Journal of Geriatrics and Gerontology

Brazilian

Boundaries of gender Brazilia and sexuality in old age. Journal

of social

sciences

\section{Importance attached \\ to sex for seniors in \\ the city of Porto Alegre \\ and association with \\ the self-perception of \\ health and happiness. \\ Sexual satisfaction \\ among elderly men \\ primary care users.}

Improvement of older

women's sexuality

through emancipatory

education

\section{Author}

Moraes, K.M:

Vasconcelos, D.P:

Silva, A.S.R; Silva,

R.C.C; Santiago,

L.M.M; Freitas,

C.A.S.L.

Debert, G.;

Brigeiro, $\mathrm{M}$.
Brazilian

Journal of

Geriatrics

and

Gerontology

r., Schneider, R.H.

Health and Silva, V.X.L.;

Society Marques, A.P.O.

Lyra, J.; Medrado,

B.; Leal, M.C.C.

Raposo, M.C.F.

Health Care Baldissera,V.D.A

for Women Bueno, S.M.V;

International Hoga A.K.
Year

2011

Research Type and Objective

cith a qualitative approach, which sought to understand about how the elderly couple experience sexuality in order to glimpse new perspectives of care, from Transpersona Care Theory of Jean Watson.

2012 Integrative review, which aimed to describe the characteristics of the process of "the stranger was sleek old age", discussing some of their possible meanings within the framework of the contemporary forms of management of aging and analyze the differentiations of genre that they operate, as well as certain mixtures.

2012 Cross-sectional study. Check the objective importance attached to sex for seniors in the city of Porto Alegre-RS, Brazil, and analyze the association with the self-perception of health and feeling of happiness.

2012 Quantitative research of cross-section, which sought to investigate the sexual satisfaction among elderly men users of the Family Health Strategy of the Recife.

2012 Action-research in order to explore the ways that sexuality is experienced daily by the elderly and improve the expression of sexuality of older women.

\section{Main Results}

There are important facets as the existence of feelings of love, respect, complicity, but also decrease in the standard of sexual activity, beyond the prejudice in relation to manifestation of affection between the gerontes and strengthening the bond over the years.

Is this discrimination against the older repressing their sexuality the myth of old age asexual and sexuality goes beyond the sexual act. Men are more interested in sex compared to women, being impossible to imagine the quality of life without the sexual dimension fully achieved.

542 elderly $(57.8 \%)$ considered the sex very important or important. There was significant difference $(p<0.001)$ in the importance given to sex for men and women, and no significant association was observed between importance attached to sex and feeling of happiness ( $p=0.299$ ).

$83 \%$ live with a mate and $89.7 \%$ of them consider this relationship as good or great, $73 \%$ claim to remain sexually active, and those with up to 70 years and cohabiting with a partner the most sexual frequency and Association was observed between current sexual satisfaction and age, selfperceived health, sexual satisfaction before the age of 60 years and the sexual frequency.

Improvement of self-esteem as a way to promote sexuality sexuality undermined by loneliness and lack of affection, sexual satisfaction of men seen as a woman's obligation, sexuality of women controlled by society and abandonment of companion to meet the expectations of family members. 


\begin{tabular}{|c|c|c|c|c|c|}
\hline $\begin{array}{l}\text { Title the } \\
\text { research }\end{array}$ & journal & Author & Year & $\begin{array}{l}\text { Research Type } \\
\text { and Objective }\end{array}$ & Main Results \\
\hline $\begin{array}{l}\text { The perception } \\
\text { of the elderly } \\
\text { man about } \\
\text { sexuality and } \\
\text { AIDS. }\end{array}$ & $\begin{array}{l}\text { Journal of } \\
\text { Nursing }\end{array}$ & $\begin{array}{l}\text { Arduini, J.B; } \\
\text { Santos, A.S. }\end{array}$ & 2013 & $\begin{array}{l}\text { Qualitative research in order } \\
\text { to understand and analyse the } \\
\text { perceptions of older men in } \\
\text { relation to sexuality and AIDS. }\end{array}$ & $\begin{array}{l}\text { Is this sexist idea about sexuality; } \\
\text { low-performance ratio of sexuality } \\
\text { that is associated with the use of } \\
\text { medications, diseases and condom } \\
\text { use; ignorance about AIDS and } \\
\text { groups at risk, as well as AIDS } \\
\text { relationship with death. }\end{array}$ \\
\hline $\begin{array}{l}\text { Factors that } \\
\text { interfere with } \\
\text { the sexuality } \\
\text { of the elderly: } \\
\text { an integrative } \\
\text { review. }\end{array}$ & $\begin{array}{l}\text { Science and } \\
\text { Collective } \\
\text { Health }\end{array}$ & $\begin{array}{l}\text { Alencar, D.L.; } \\
\text { Marques, } \\
\text { A.P.O.; Leal, } \\
\text { M.C.C.; Vieira, } \\
\text { J.C.M. }\end{array}$ & 2014 & $\begin{array}{l}\text { Integrative review. Objective to } \\
\text { analyze the scientific evidence } \\
\text { that discuss factors that } \\
\text { interfere with the sexuality of } \\
\text { the elderly. }\end{array}$ & $\begin{array}{l}\text { Absence of the partner due to } \\
\text { widowhood, valuing the standard } \\
\text { of youthful exuberance, occurrence } \\
\text { of disease, use of medicines and } \\
\text { changes in sexual physiology were } \\
\text { identified as important factors that } \\
\text { influence the sexuality of older. }\end{array}$ \\
\hline
\end{tabular}

jority approaches show more the subjectivity of the public discourse researched, giving greater relevance to this review.

The population investigated in these field trials was varied, four studies investigated elderly, two, elderly, one, elderly couples and conducted with seniors and elderly, it is important for this review by presenting a vision of sexuality by male and female public the third age. The majority of studies (07) were performed by nurses, showing an increased interest in this area to develop research into this important issue, and 01 study by medical field 01 in the field of therapy and 01 in the area of sociological.

\section{Discussion}

For a better understanding of the discussion will be presented in the following three categories:

\section{Category 1. Definition of sexuality and social roles}

With the analysis of articles it was possible to conclude that the definition of sexuality for some elderly is complex and more targeted the experiences and affection received by the spouse or partner and still others relate this term with the sexual act itself, or unaware of the this theme. In a study to investigate the perception of elderly about sexuality, it was noted that most understood it as just as sex, but some of them also included love, affection, friendship and fellowship in its definition, and a minority demonstrated a lack of understanding on the issue [7].

In the speeches of the elderly couples investigated in a survey there were demonstrated different ways of understanding sexuality and there is a greater awareness of feelings associated with it away from the sexual act itself, some define it as love, respect, understanding, friendship and unity [8], which confirms the great importance given by the elderly to the psychological aspect of sexuality.

It becomes easier verbalization of sexuality when it is part of reality built during daily life, and among elderly participants of this term research was not played due to report not having active sex life and supposedly because it was not placed in dialogue over time, which creates a silence to speak on the subject, showing that sexuality is something that should not be spoken by the elderly [9].

It is common to see some resistance by the elderly to comment about sexuality, because education received many times in their past is repressing or precarious or even exclusively associates sexuality to sex and that is wrong in society, manifest their sexual desires suffering prejudice and repressing to 
talk about it and that too to be going through the aging process, is unable to demonstrate and experience their sexuality.

Studies show it is proper of societies to suppress the sexuality of older people with discrimination, and not just part of the youngest, but also the older people themselves. The "old age myth asexual" emerges as a consensus in gerontology, which associates the end of sex life with old age [10].

The model of education received in the past is not the only factor to institute asexuality the elderly, in addition, it has a repressive society. But even with the arrival of old age the body maintains its manifestations of sexuality and can often be evaluated by the social environment prejudiced or as inconsiderate impulses. All this contributes to the elderly to experience their sexuality with guilt or not to experience [11].

The concept of sexuality of men and women is presented differently; men tend to focus their interests in the genital region and penetration and are described as more interested in sex. Regarding the elderly, these tend to indicate sexuality as something more complex [10]. In two studies conducted with older they demonstrated that they say have some obligation to meet the needs of men, not taking into account their wishes and that failure in this conjugal performance served as synonymous with the end of marriage $[9,12]$.

\section{Category 2. Aging and Sexuality: interfering factors}

The issues that seem to interfere more in the sex life of the elderly interviewed men in a survey, are the health conditions of the elderly or their partner, since the results show that the elderly dissatisfied with their health has 1.7 times more chances of being dissatisfied with their sex lives than those who were satisfied with their health [13].

Converging with the above information, a survey conducted with 938 elderly in Porto Alegre-RS, it was evident that there is a greater allocation of im- portance to sex by those who have better health perception [14], suggesting that good health is directly related to better performance of sexuality and sex of the elderly, requiring an approach by health professionals, on interference in the sexuality of those with diseases helping to minimize existing problems.

It is necessary to evaluate the impact of the disorder on sexuality, since these elderly are more vulnerable to develop emotional and social isolation problems. The elderly, because they are more likely to physiological changes that affect sexuality can direct this experience to other activities such as self-care. It is also observed that many of them, especially women, are dissatisfied with their body image and this leads to a decrease or absence of affective relationships and refusal to sex [15], an integral approach of the elderly it is necessary guiding for self-care with consequent improvement in selfesteem.

Adding to these claims, a case study with elderly couples showed that aging causes also changes in desire and sexual interest, comparing this experience in the present with the past and pointing as a significant factor of change in the couple's relationship and that it would be related pathologies and use of medications. But even with the decrease or absence of sexual intercourse, remained the love and unity in a lasting relationship [8] which shows that the elderly couple attaches great importance to the friendship and union which essentially and exclusively to the sexual act.

Other research has shown the presence of diseases arising from senescence and the use of drugs as contributing factors to the decrease sexual, among the diseases cited high blood pressure was the main chronic injury remembered [16].

Widowhood was also a factor cited in the analysis of some studies showing that loneliness and lack of affection were problems that hampered the sexuality of older, agreeing that the existence of a companion is more important than sex. In addition, 
another study showed the difficulty of the elderly surveyed to find another companion of the same age because there are a greater number of widows and also be the influences of the society in which they were raised and educated to have a single partner for life [7 12].

Despite all these changes in the aging process, it may be possible to keep an active sexuality even in old age; it is the practice of sexual activity, either through feelings explained in the above studies, it is important to provide information for healthy sexuality, one as it is closely associated with improved self-esteem and quality of life of the elderly.

\section{Category 3. Sexuality and Health Education}

Education for sexuality to be worked with the elderly in all health care levels and especially at the primary level which is more focused on the promotion of health through health education. It is noticed that there is some difficulty in talking about this issue with the elderly because of the stereotypes already set by society who preach the asexual old age, considering the bad old express their sexuality.

Behind the social representation "did not understand sexuality". There is an anti-dialogical movement, because even though sexuality is inherent to the individual, if not placed in dialogue becomes unknown to discuss. In this way, health education is important to create opportunities spaces that put the sexuality debate and collaborate to dialogicity among the elderly [9].

It is inferred that the elderly have not received information on the subject in their youth, because of past culture, it could be verified in a study that when questioned if older received information adolescent about sexuality most answered not, and only one received friends. In his speech presented in the survey, it shows the difficulty that the family had to discuss this issue, since it would be shameful and marriages still happen in adolescence without getting to know well what would experience [7].
Thus, health education becomes an important and necessary strategy for building concepts that see the elderly as a human being free and able to experience their sexuality without myths and prejudices that are still present and strong in society and is necessary to involve the elderly and non-elderly, it becomes important to discuss this issue at all stages of life, since aging is inevitable in humans [15].

It is important to note that this review has limitations, since there are few field research numbers performed with seniors about sexuality and that in most studies there are interviews with elderly women, requiring more approaches regarding the experience of males. Moreover, the small number of research makes repeated a few times in the categories shown above.

\section{Conclusion}

This review showed that the definition of sexuality by older people goes beyond the biological factor being represented by more feelings, considered more important than the sexual act itself. In addition, the aging comes accompanied by organic and physical changes that affect the performance of their sexuality. Finally, it is necessary to develop health education strategies for seniors and young people in care areas to provide important information about aging and sexuality, contributing to a successful and healthy aging.

It is expected, therefore, that this study can enable reflections about the need to address naturally sexuality in old age and stimulate it, since it is connected fully to a good quality of life and improved the old self-esteem, without prejudice or repression towards them. Adding to this, it is intended that further researches can be developed and that the health team can look for the seniors to be awakened, turning to their completeness and leaving them free to share their matters and experiences of sexuality. 


\section{References}

1. Brasil. Ministério da Saúde. Secretaria de Atenção à Saúde. Departamento de Ações Programáticas e Estratégicas, Área Técnica Saúde do Idoso. Atenção à saúde da pessoa idosa e envelhecimento. $1^{\text {a }}$ ed. v. 12, 44 p. Brasília: Editora do Ministério da Saúde, 2010. p. 11-16 Disponível em: http://bvsms.saude. gov.br/bvs/publicacoes/atencao saude pessoa idosa envelhecimento $v 12$.pdf

2. Ibge. Instituto Brasileiro de Geografia e Estatística. Comunicação social: projeção da população do Brasil. 2009. Disponível em: http://www.ibge.gov.br/home/estatistica/populacao/projecao da populacao/2008/projecao.pdf

3. Bessa MEP, Viana AF, Bezerra CP, Sousa LB, Almeida JJA, Wanderley LWB. Percepção de idosos residentes em instituições de longa permanência acerca da sexualidade na terceira idade. Cadernos da Escola de Saúde Pública, 2010; 4 (2): 19-24. Disponível em: http://www.esp.ce.gov.br/cadernosesp/index. php/cadernosesp/article/view/36/32

4. Rabelo DF, Lima CFM. Conhecimento e Atitude de Futuros Profissionais da Saúde em Relação à Sexualidade na Velhice. Revista Temática Kairós Gerontologia, 2011; 14(5): 163-180. Disponível em: http://revistas.pucsp.br/index.php/kairos/article/ view/9909/7363

5. Crossetti MGO. Revisão integrativa de pesquisa na enfermagem o rigor cientifico que the é exigido. Rev Gaúcha Enferm., 2012; 33(2): 8-9. Disponível em: http://www.scielo.br/pdf/rgenf/ v33n2/01.pdf

6. Mendes KDS, Silveira RCCP, Galvao CM. Revisão integrativa: método de pesquisa para a incorporação de evidências na saúde e na enfermagem. Texto contexto - enferm., 2008; 17(4): 758764. Disponível em: http://www.scielo.br/scielo.php?script=sci arttext\&pid=S0104-07072008000400018\&lng=en\&nrm=iso

7. Frugoli A, Magalhães Júnior CAO. A sexualidade na terceira idade na percepção de um grupo de idosas e indicações para educação sexual. Arq. Ciênc. Saúde UNIPAR, 2011; 15(1): 83-95. Disponível em: http://revistas.unipar.br/saude/article/ view/3696/2398

8. Moraes KM, Vasconcelos DP, Silva ASR, Silva RCC, Santiago LMM, Freitas CASL. Companheirismo e sexualidade de casais na melhor idade: cuidando do casal idoso. Rev. Bras. Geriatr. Gerontol., 2011; 14(4): 787-798. Disponível em: http://www. scielo.br/pdf/rbgg/v14n4/a18v14n4.pdf

9. Baldissera VDA, Bueno SMV. A representação da sexualidade por idosas e a educação para a saúde. Rev. Eletr. Enf. [online], 2010; 12(4): 622-629. Disponível em: https://www.fen.ufg.br/ fen revista/v12/n4/v12n4a05.htm

10. Debert G, Brigeiro M. Fronteiras de gênero e a sexualidade na velhice. Rev. bras. Ci. Soc., 2012; 27(80): 37-54. Disponível em: http://www.scielo.br/scielo.php?script=sci_arttext\&pid=S0102$69092012000300003 \& \operatorname{lng}=e n \& n r m=i s 0$
11. Coelho DNP, Daher DV, Santana RF, Santo FHE. Percepção de mulheres idosas sobre sexualidade: implicações de gênero e no cuidado de enfermagem. Rev. Rene., 2010; 11(4): 163-173. Disponível em: http://www.revistarene.ufc.br/revista/index.php/ revista/article/view/443/pdf

12. Baldissera VDA, Bueno SMV, Hoga AK. Improvement of older women's sexuality through emancipatory education. Health Care for Women International, 2012; 33: 956-972.

13. Silva VXL, Marques APO, Lyra J, Medrado B, Leal MCC, Raposo MCF. Satisfação sexual entre homens idosos usuários da atenção primária. Saude Soc., 2012; 21(1): 171-180. Disponível em: http://www.scielo.br/scielo.php?script=sci arttext\&pid=S0104$12902012000100017 \&$ lng $=$ en\&nrm=iso

14. Bastos CC, Closs VE, Pereira AMVB, Batista C, Idalêncio FA, Carli GA, Gomes I, Schneider RH. Importância atribuída ao sexo por idosos do município de Porto Alegre e associação com aautopercepção de saúde e o sentimento de felicidade. Rev. bras. geriatr. gerontol., 2012; 15(1): 87-95. Disponível em: http://www.scielo.br/scielo.php?script=sci arttext\&pid=\$180998232012000100010\&lng=en\&nrm=iso

15. Alencar DL, Marques APO, Leal MCC, Vieira JCM. Fatores que interferem na sexualidade de idosos: uma revisão integrativa. Ciênc. saúde coletiva, 2014; 19(8): 3533-3542. Disponível em: http://www.scielo.br/scielo.php?script=sci arttext\&pid=S1413$81232014000803533 \& \operatorname{lng}=e n \& n r m=i s 0$

16. Arduini JB, Santos AS. A percepção do homem idoso sobre sexualidade e AIDS. Rev. enferm. UERJ, 2013; 21(3): 379-83. Disponível em: http://www.facenf.ueri.br/v21n3/v21n3a17.pdf
Publish in International Archives of Medicine

International Archives of Medicine is an open access journal publishing articles encompassing all aspects of medical science and clinical practice. IAM is considered a megajournal with independent sections on all areas of medicine. IAM is a really international journal with authors and board members from all around the world. The journal is widely indexed and classified Q2 in category Medicine. 